\title{
Opening the Black Box of Psychological Processes in the Science of Sustainable Development: A New Frontier
}

\author{
Annamaria Di Fabio ${ }^{1 *}$, Marc A. Rosen ${ }^{2}$ \\ ${ }^{1}$ Department of Education and Psychology (Psychology Section), University of Florence, via di San Salvi, 12, Complesso \\ di San Salvi, Padiglione 26, 50135 Firenze, ITALY \\ ${ }^{2}$ Faculty of Engineering and Applied Science, University of Ontario Institute of Technology, 2000 Simcoe Street North, \\ Oshawa, Ontario, L1G 0C5, CANADA
}

*Corresponding Author: adifabio@psico.unifi.it

Citation: Di Fabio, A. and Rosen, M. A. (2018). Opening the Black Box of Psychological Processes in the Science of Sustainable Development: A New Frontier. European Journal of Sustainable Development Research, 2(4), 47. https://doi.org/10.20897/ejosdr/3933

Published: October 31, 2018

\begin{abstract}
The psychology of sustainability and sustainable development represents a new research area in the field of Sustainability Science. It introduces a psychological perspective and enhances the trans-disciplinary framework that forms the foundation of Sustainability Science. Firmly establishing the psychology of sustainability and sustainable development as a research area means recognizing and integrating the value of psychology and the psychological approach in the construction of processes linked to sustainable development. Enriching sustainable development through opening the black box of psychological processes in support of sustainable development is a new and exciting frontier, that will likely lead to major developments and concrete advances for making development more sustainable in the 21 st century and beyond.
\end{abstract}

Keywords: psychology of sustainable development, psychology of sustainability, sustainable development, sustainability

\section{INTRODUCTION}

Sustainability Science creates a trans-disciplinary reflection space that combines natural and applied sciences, social sciences, and humanities (Dincer and Rosen, 2013; Rosen, 2009, 2017a). It is centered on investigating the interactions between human, environmental and engineered systems in order to try to understand the complex factors that contribute to their degradation, to preserve the planet for the future and to promote human well-being. The range of disciplines to which sustainable development and sustainability principles apply is very broad, as demonstrated quantifiably in a recent study (Tang et al., 2018). Many examples of projects and proposals, but small and large, that bring various disciplines together to address sustainable development exist. For example, the RedMediterranean-Dead Seas Canal Project has been touted as a pragmatic approach for sustainable development that merges technical and social issues extensively (Rosen and Abu Rukah, 2011).

Sustainability Science contributes directly to the UN Sustainable Development Goals (United Nations, 2018), which extend to 2030 and which are important for humanity. These goals address significant global challenges included poverty, inequality, climate change, environmental degradation, prosperity, peace, justice and human well- 
being. As the UN Sustainable Development Goals formally came into effect in January 2016, many wondered how we can achieve them. In trying to address this question, it is clear that contributions are needed from a very broad range of fields and disciplines, and certainly more than just the technical ones (Rosen, 2017b).

The psychology of sustainability and sustainable development (Di Fabio, 2017a, 2017b, 2018) represents a new research area in the field of Sustainability Science. It contributes to sustainability issues by introducing a psychological perspective and enhancing the trans-disciplinary framework that forms the foundation of Sustainability Science. Firmly establishing the psychology of sustainability and sustainable development as a research area, rather than one that only provides sporadic contributions, often only in terms of theoretical reflections, means recognizing and integrating the value of psychology and the psychological approach in the construction of processes linked to sustainability and sustainable development. This is primarily important in terms of environmental sustainability and sustainable development in relation to the natural environment, as psychological processes are often involved in environmental decisions and behavior as well as in developing and establishing a culture of sustainability regarding the natural environment. In fact, many of the related decisional and behavioral processes are substantiated primarily by internal psychological processes within the individual. Facilitating these processes requires that they be studied and understood better. The innovative psychological research perspective encompassed in the psychology of sustainability and sustainable development is critical for that.

This is also true not only in relation to the sustainability of the natural environment or in relation to the traditionally broader perspective of sustainability in terms of ecological, social and economic dimensions, but also with respect to the psychological environment that is aimed at improving the quality of life for individuals and communities. The traditional perspective centered on the 3 "E's" of economy, equity, and ecology (Brundtland Report, "Our Common Future", 1987; Harris, 2003) is focused on avoiding exploitation, depletion and irreparable alteration. The psychology of sustainability and sustainable development goes beyond this traditional perspective and introduces a framework focused not only on using increasingly smaller quantities of resources but also on regenerating resources and on a positive approach. That approach is based on new keywords such as promotion, enrichment, growth, flexible change (Di Fabio, 2017a, 2017b). There is a shift in the focus from pressure to the challenge to find new solutions, from small amounts of resources to regenerating resources, from damage/threat to opportunity/change. The psychology of sustainability and sustainable development creates a new axis of psychological reflection on what is really sustainable for individuals in the environments, including the ecological environment. It considers a meaningful and sustainable construction, with coherence, direction, significance, and belonging (Di Fabio, 2017b). Sustainability and sustainable development anchored to a psychological perspective, asks for the construction of authentic meanings for individuals and communities, underlining the importance of connections, meaning and purpose (Di Fabio and Blustein, 2016). It incorporates spatial and temporal perspectives, and seeks to harmonize the complexity in relation to each person and the others (Di Fabio, 2018).

The psychology of sustainability and sustainable development tries to contribute to the sustainability and sustainable development of every person, facilitating the flourishing of his/her talents, not only in terms of interpersonal but also intrapersonal talents, for the benefit of the community of belonging and progress. But it is also focused on the well-being and the quality of life of the environment, and of each person both in the natural environment and in the other kinds of environments.

The psychology of sustainability and sustainable development is focused on the well-being of the person and of well-being of the environment, and also of the person in the environment, considering different kinds of environments: natural, personal, social, organizational, community, global and cross-cultural environments (Di Fabio, 2018).

The psychology of sustainability and sustainable development perspective could yield contributions from a preventive perspective, perhaps by implementing research and interventions from a primarily preventative perspective (Di Fabio and Kenny, 2015, 2016; Hage et al., 2007; Kenny and Hage, 2009) and focusing on crucial psychological aspects to concretely progress towards sustainability and sustainable development.

We already have crucial empirical evidence on the need for implementing this new research area and more will almost certainly be gained in the future. Some brief examples are provided for illustration. Regarding the natural environment, we have research results related to the connectedness to nature and the critical variables to improve it. Understanding how to improve people's connection to nature is a vital research area in understanding behaviors that underpin sustainability efforts (Mayer and Frantz, 2004; Di Fabio, 2018). Accounting for personality traits, which are traditionally considered stable in the literature, connectedness to nature as a dependent variable was found to be associated with empathy (Di Fabio and Bucci, 2016; Di Fabio and Kenny, in press), emotional intelligence (Di Fabio, 2018) and other constructs such as positive relational management (Di Fabio, 2016), academic relational civility (Di Fabio and Kenny, 2018), workplace relational civility (Di Fabio and Gori, 2016a) and human capital sustainable leadership (Di Fabio and Peiro, 2018). These results suggest that variables that are malleable and that can be enhanced with specific training, emerged as important resources useful both for the well- 
being of people in their social environments and also for the construction of positive attitudes towards the natural environment. Attitudes in achieving positive outcomes through sustainability measures were examined in an engineering context and shown to be of great significance (Rosen, 2013).

Regarding personal environment, we have research results on personal resources that have positive relationships with the well-being of individuals in different environments, also accounting for the effects of personality traits. These results relate to intrapreneurial self-capital (Di Fabio, 2014), life project reflexivity (Di Fabio, Maree, and Kenny, 2018) and acceptance of change (Di Fabio and Gori, 2016).

Regarding the social environment, empirical studies show that both positive relational management and academic relational civility are able to provide contributions to the well-being of people beyond personality traits (Di Fabio, 2018).

Regarding the organizational environment, workplace relational civility and human capital sustainability leadership have been observed to be associated to well-being (Di Fabio, 2018) in terms of positive resources to promote humane, productive and healthier organizations, supporting sustainable development and the flourishing of workers. All of these variables are capable of enhancement, unlike typical personality traits.

These empirical results permit us to widen the perspective on the community environment, the global environment and the cross-cultural environment, focusing on strengths and resources and their use in a preventative perspective and as a bridge between the natural environment, the person, the group, the organization, the community and countries (Di Fabio, 2018).

Consider as an example the field of energy. Much work has been done to make energy utilization and energy systems more sustainable, including efforts related to such energy sources as geothermal energy (Rosen and KoohiFayegh, 2017), bioenergy (Sansaniwal et al., 2017) and many others (Dincer and Rosen, 2013), as well as such technologies as heating and cooling (Rosen and Koohi-Fayegh, 2017) and gasification of solids (Sansaniwal et al., 2017). It has become increasingly clear that issues related to social sciences, including psychology, are needed to make such work more implementable successfully. Consequently, new models have been put forward that take into account a broad array of factors in assessing the sustainability of energy systems (Hacatoglu et al., 2015), and optimization methods for energy systems are being expanded to take into account a broader array of factors related to sustainability (Dincer et al., 2017). The inclusion of principles from the psychology of sustainability and sustainable development is needed in such work. The Red-Mediterranean-Dead Seas Canal Project referred to earlier (Rosen and Abu Rukah, 2011) is a good example of how a project that deals with energy issues as well as societal needs can greatly benefit from incorporating the psychology of sustainable development.

The psychology of sustainability and sustainable development is a new research area that can contribute to expanding the horizons of sustainable development and related disciplines. Enriching sustainable development through opening the black box of psychological processes in support of the science of sustainable development is a new and exciting frontier, that will likely lead to major developments and concrete advances for making development more sustainable in the $21^{\text {st }}$ century and beyond.

\section{REFERENCES}

Brundtland Report (1987). Our Common Future. New York, NY: Butterworth.

Di Fabio, A. (2014). Intrapreneurial Self-Capital: A new construct for the $21^{\text {st }}$ century. Journal of Employment Counseling, 51, 98-111. https:// doi.org/10.1002/j.2161-1920.2014.00045.x

Di Fabio, A. (2016). Positive Relational Management for healthy organizations: Psychometric properties of a new scale for prevention for workers. In G. Giorgi, M. Shoss, and A. Di Fabio (Eds.), From organizational welfare to business success: Higher performance in healthy organizational environments. Research Topic in Frontiers in Psychology. Organizational Psychology, 7, 1523. https://doi.org/10.3389/fpsyg.2016.01523

Di Fabio, A. (2017a). Positive Healthy Organizations: Promoting well-being, meaningfulness, and sustainability in organizations. In G. Arcangeli, G. Giorgi, N. Mucci, J.-L. Bernaud, and A. Di Fabio (Eds.), Emerging and reemerging organizational features, work transitions and occupational risk factors: The good, the bad, the right. An interdisciplinary perspective. Research Topic in Frontiers in Psychology. Organizational Psychology, 8, 1938. https://doi.org/10.3389/fpsyg.2017.01938

Di Fabio, A. (2017b). The psychology of sustainability and sustainable development for well-being in organizations. In G. Arcangeli, G. Giorgi, N. Mucci, J.-L. Bernaud, and A. Di Fabio (Eds.), Emerging and re-emerging organizational features, work transitions and occupational risk factors: The good, the bad, the right. An interdisciplinary perspective. Research Topic in Frontiers in Psychology. Organizational Psychology, 8, 1534. https://doi.org/10.3389/fpsyg.2017.01534

Di Fabio, A. (2018). The psychology of sustainability and sustainable development for decent work, innovation and social inclusion: theory, research and practice. Keynote at the One-Day International Conference "Decent work and sustainable 
development: the perspective of existential psychology for innovation and social inclusion", organized by the Department of Education and Psychology, University of Florence, Florence, Italy, September 21, 2018.

Di Fabio, A. and Blustein, D. L. (Eds). (2016). Ebook Research Topic From Meaning of Working to Meaningful Lives: The Challenges of Expanding Decent Work. Lausanne: Frontiers Media. https:/ / doi.org/10.3389/978-2-88919-9709 (Ebook).

Di Fabio, A. and Bucci, O. (2016). Green positive guidance and green positive life counseling for decent work and decent lives: Some empirical results. In A. Di Fabio \& D. L. Blustein (Eds.), From meaning of working to meaningful lives: The challenges of expanding decent work. Research Topic in Frontiers in Psychology. Section Organizational Psychology, 7, 261. https://doi.org/10.3389/fpsyg.2016.00261

Di Fabio, A. and Gori, A. (2016a). Assessing Workplace Relational Civility (WRC) with a new multidimensional "mirror" measure. In A. Di Fabio \& D. L. Blustein (Eds.), From meaning of working to meaningful lives: The challenges of expanding decent work. Research Topic in Frontiers in Psychology. Section Organizational Psychology, 7 , 890. https:/ / doi.org/10.3389/fpsyg.2016.00890

Di Fabio, A. and Gori, A. (2016b). Developing a new instrument for assessing Acceptance of Change. Frontiers in Psychology. Section Organizational Psychology, 7, 802. https://doi.org/10.3389/fpsyg.2016.00802

Di Fabio, A. and Kenny, M. E. (2015). The contributions of emotional intelligence and social support for adaptive career progress among Italian youth. Journal of Career Development, 42, 48-59. https://doi.org/10.1177/0894845314533420

Di Fabio, A. and Kenny, M. E. (2016). From decent work to decent lives: Positive Self and Relational Management (PS\&RM) in the twenty-first century. In A. Di Fabio \& D. L. Blustein (Eds.), From meaning of working to meaningful lives: The challenges of expanding decent work. Research Topic in Frontiers in Psychology. Section Organizational Psychology, 7, 361. https://doi.org/10.3389/fpsyg.2016.00361

Di Fabio, A. and Kenny, M. E. (2018). Academic relational civility as a key resource for sustaining well-being. Sustainability, 10, 1914. https:// doi.org/10.3390/su10061914

Di Fabio, A. and Kenny, M. E. (in press), Connectedness to Nature, Personality Traits and Empathy from a Sustainability Perspective. Current Psychology.

Di Fabio, A., Maree, J. G. and Kenny, M. E. (2018). Development of the Life Project Reflexivity Scale: A new career intervention inventory. Journal of Career Assessment, 1-13. https://doi.org/10.1177/1069072718758065

Di Fabio, A. and Peiró, J. M. (2018). Human Capital Sustainability Leadership to promote sustainable development and healthy organizations: A new scale. Sustainability, 10, 1914. https://doi.org/10.3390/su10061914

Di Fabio, A., Palazzeschi, L. and Bucci, O. (2017). In an unpredictable and changing environment: Intrapreneurial Self-Capital as a key resource for life satisfaction and flourishing. In G. Arcangeli, G. Giorgi, N. Mucci, J.-L. Bernaud, \& A. Di Fabio (Eds.), Emerging and re-emerging organizational features, work transitions and occupational risk factors: The good, the bad, the right. An interdisciplinary perspective. Research Topic in Frontiers in Psychology. Organizational Psychology, 8, 1819. https://doi.org/10.3389/fpsyg.2017.01819

Dincer, I. and Rosen, M. A. (2013). Exergy energy, environment and sustainable development. 2nd ed. Amsterdam: Elsevier Science Publishers.

Dincer, I., Rosen, M. A. and Ahmadi, P. (2017). Optimization of Energy Systems. London: Wiley. https://doi.org/10.1002/9781118894484

Hacatoglu, K., Dincer, I. and Rosen, M. A. (2015). A new model to assess the environmental impact and sustainability of energy systems. Journal of Cleaner Production, 103, 211-218. https://doi.org/10.1016/j.jclepro.2014.06.050

Hage, S. M., Romano, J. L., Conyne, R. K., Kenny, M., Matthews, C., Schwartz, J. P. and Waldo, M. (2007). Best practice guidelines on prevention practice, research, training and social advocacy for psychologists. The Counseling Psychologist, 35, 493-566. https:// doi.org/10.1177/0011000006291411

Harris, J. M. (2003). Sustainability and sustainable development. International Society for Ecological Economics, 1(1), 112.

Kenny, M. E. and Hage, S. M. (2009). The next frontier: Prevention as an instrument of social justice. The Journal of Primary Prevention, 30, 1-10. https:// doi.org/10.1007/s10935-008-0163-7

Mayer, F. S. and Frantz, C. M. (2004). The connectedness to nature scale: A measure of individuals' feeling in community with nature. Journal of Environmental Psychology, 24(4), 503-515. https://doi.org/10.1016/j.jenvp.2004.10.001

Rosen, M. A. (2009). Energy sustainability: A pragmatic approach and illustrations. Sustainability, 1(1), 55-80. https://doi.org/10.3390/su1010055

Rosen, M. A. (2013). Engineering and sustainability: attitudes and actions. Sustainability, 5(1), 372-386. https://doi.org/10.3390/su5010372

Rosen, M. A. (2017a). Sustainable development: a vital quest. European Journal of Sustainable Development Research, 1(1), 2. https://doi.org/10.20897/ejosdr.201702 
Rosen, M. A. (2017b). How can we achieve the UN Sustainable Development Goals? European Journal of Sustainable Development Research, 1(2), 06.

Rosen, M. A. and Abu Rukah, Y. (2011). A pragmatic approach for sustainable development of the RedMediterranean-Dead Seas Canal Project: a case study. Int. J. Ecology \& Development, 19(S11), 63-75.

Rosen, M. A. and Koohi-Fayegh, S. (2017). Geothermal Energy: Sustainable Heating and Cooling Using the Ground. London: Wiley. https://doi.org/10.1002/9781119181002

Sansaniwal, S. K., Rosen, M. A. and Tyagi, S. K. (2017). Global challenges in the sustainable development of biomass gasification: an overview. Renewable and Sustainable Energy Reviews, 80, 23-43. https://doi.org/10.1016/j.rser.2017.05.215

Tang, M., Liao, H., Wan, Z., Herrera-Viedma, E. and Rosen, M. A. (2018). Ten years of Sustainability (2009 to 2018): a bibliometric overview. Sustainability, 10(5), 1655. https://doi.org/10.3390/su10051655

United Nations (2018). About the Sustainable Development Goals. Available at: https://www.un.org/sustainabledevelopment/sustainable-development-goals 